\title{
IN SEARCH OF THE SORCERER'S APPRENTICE: BETWEEN LUCIAN AND WALT DISNEY ${ }^{46^{*}}$
}

\author{
Damian KaLITAN \\ damian.kalitan@uj.edu.pl \\ Jagiellonian University Kraków, \\ Poland
}

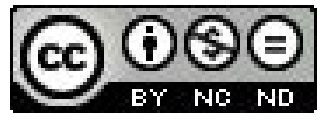

\begin{abstract}
At first glance, the movie by Jon Turteltaub entitled The Sorcerer's Apprentice (2010) seems not to have any connections with Greco-Roman antiquity whatsoever. To find the hidden connection we have to go back to year 1797 when Johann Wolfgang Goethe published his famous ballad Der Zauberlehrling (The Sorcerer's Apprentice) Almost a century later, this work inspired a French composer Paul Dukas to write his masterpiece, the symphonic scherzo L'apprenti sorcier. Dukas' music became the leitmotif of both Disney's movies: Fantasia (1940) and Fantasia 2000 (1999) whose action is based on Goethe's ballad. Also, the basic elements of the plot were used in one of the episodes of the series Alfred Hitchcock Presents (1961). This is where we touch the ancient roots of the story. A good friend of J.W. Goethe, Christoph Martin Wieland, happened to have published in 1789 the first complete German translation of Lucian of Samosata's (120-180 AD) works, including a dialogue entitled Philopseudes (The Lover of Lies). The tenth story told in Philopseudes turned out to be very similar to the one written by J. W. Goethe and then adapted into Disney's and Turteltaub's movies. In my paper I try to show the transmission of the Lucianic text from antiquity to modern film adaptations. The original Lucian tale, rewritten by J.W. Goethe, becomes very influential. The so-called "sorcerer's apprentice syndrome" can be found at the root of many fantastic stories in which humans could not curb their creations (i.e. robots) which eventually would turn against their makers. The primary focus of this paper is on how the story of a young apprentice changed over centuries and how it was adopted by cinematography.
\end{abstract}

Key words: Lucian, Sorcerer, Apprentice, reception, Walt Disney, Paul Dukas, film, Fantasia

On December $17^{\text {th }} 1999$, an animated film, entitled Fantasia 2000, which had been worked on for several years, had its world premiere and for many years remained very popular. Encouraged by the film's success and inspired by one of the scenes, Walt Disney Pictures decided to make The Sorcerer's Apprentice directed by Jon Turteltaub. Looking for the origins of the idea of a young magician, used in both movies, we can immediately find the information that the inspiration was drawn from Goethe's ballad from the year 1797 called Der Zauberlehrling (The Sorcerer's Apprentice). However, the source of this motif is to be found in antiquity. In the $19^{\text {th }}$ and $20^{\text {th }}$ centuries the ancient roots of this story were already forgotten and all the merits

${ }_{46}$ *Many thanks to Paulina Pietrzyk for her invaluable help with translation of this paper. 
attributed to Johann Wolfgang Goethe. This paper seeks to identify the original inspiration for the motif of a wizard's young student. To do so, it seems necessary to examine the writings of a $2^{\text {nd }}$ century Greek writer Lucian of Samosata.

Lucian of Samosata was a leading representative of a literary period called The Second Sophistic and one of the most original satirical Greek writers. We know about him no more than what he gave us, especially in the two dialogues which are considered to be autobiographical: The Dream or The Cock and The Double Indictment or Trials by Jury. He was born around 120 AD, in Samosata by the Euphrates in Syria, and died about 190 AD. He came from an indigent family. At first he tried to become a sculptor but quickly took to study rhetoric and philosophy. Thanks to hard work he mastered the Greek language. In the ancient sources we can find a few direct references, and very little indirect evidence of his work being known (Sinko 1951, pp. 367-444). That changed significantly in the Byzantine period.

The first important information about the writer from Samosata comes from Photius ( $9^{\text {th }}$ century AD) in the cod 128 of his work The Bibliotheca. The next mention is by Photius' student and a ferocious critic of Lucian, Arethas of Caesarea ( $9^{\text {th }}-10^{\text {th }}$ century AD). He had some manuscripts (including Lucian's texts) copied. Arethas put on them his handwritten notes (scholia) that have survived to our times (Madyda 1946, pp. 468- 476). Despite Arethas' criticism, the popularity of Lucian grew. Anonymous dialogues based on Lucian's works started to appear and they were attached to the set of his writings. Writers such as Theodore Prodromos $\left(12^{\text {th }}\right.$ century AD) imitated his style and Michael Psellos recommended reading of Lucian (Hammer 1948, pp. 27-32). Also Suda (gr. Biblion Súda) mentions the satirist and the note on him concludes: "infernal punishment that Lucian deserves will last for all forever" (Holzman 1983, pp. 29-44) ${ }^{47}$. The author of Suda was only partly right - it seems that it is Lucian's influence on culture that is apparently endless.

It is not certain when exactly Lucian's works appeared in Europe. Several options are taken into consideration. One of them indicates that Giovanni Aurispa, during his trip to Constantinopole in 1425, brought 238 Greek manuscripts, including the texts of Lucian. Other sources say that Gurino Guarini brought the manuscript about 1408, and soon published several of the works in Latin translation. Nonetheless, another source indicates that in 1397 Manuel Chrysoloras brought to Florence a manuscript with the writings of Lucian to teach his student Greek. Disagreement involves also the time of the editio princeps. Reported dates are: 1496 and 1525, but at least the place of the first edition is not a subject of dispute and is commonly accepted to be Florence ${ }^{48}$. Since the publication in print the staggering career of Lucian began. The Italian scholars, unfamiliar with the Greek language, started to adopt Lucianic texts through Latin translations. The European reception of Lucian started as early as the treatise De Pictura of Leone Battista Alberti published in 1435, where he writes: "For imagination does have such power that may interest even without the connection with the art of painting. Lucian gives a

47 Unless indicated otherwise, all quotations are translated by the author of this paper.

48 The discussion on the date of bringing the manuscript to Europe and on the date of editio princeps see: Sinko 1951, pp. 435-346; Korus 1968, p. 131; Miziołek 2003, pp. 43-46; Ligota 2007, pp. 9-13, 71-114; Goldschmidt 1951, pp. 7-20. 
description of the painting Calumny of Apelles in such a way that by reading itself you feel admiration for the art of Apelles. (...) Therefore, I suggest to a painter to be familiar with the poets, orators and other experts of literature and refer to them kindly" (Białostocki 1978, p. 112). And the painters took to the heart the words of Italian theorist and, as says Tadeusz Sinko about the Lucianic impact on the art: "even the descriptions of ancient paintings by Philostratus did not manage to set so many painting brushes in motion" (Sinko 1951, p. 429).

Knowledge of Lucian and his works quickly spread over the whole of Europe. Sandro Botticelli, Leonardo da Vinci, Raphael, Peter Paul Rubens, Albrecht Dürer, and many others drew on Lucian. It is possible to see this phenomenon by tracking the popularity of theme of calumny or the centaurs family in many Renaissance painters. The best minds of Europe were fascinated by the writer from Samosata. Erasmus of Rotterdam also was influenced by Lucian. Once he mastered Greek, he began to translate some of Lucian's dialogues like Philopseudes (The Lover of Lie) and the literary theme for his In Praise of Folly he also drew directly on Lucian (Barycz 1953, pp. XXXVI-LXXXIV). The eminent mathematician and astronomer Johannes Kepler conducted his astronomical observations inspired by True Story and Icaromenippus. He even wrote a fantastic novel, kept in Lucianic style, entitled Somnium Or Posthumous Work on Lunar Astronomy (Kepler 1967) ${ }^{49}$.

For the full understanding of the discussed motif of the sorcerer's apprentice, the further introduction to the Lucianic dialogue Philopsudes (The Lover of Lie) is necessary. The text and its literary idea is very interesting. Lucian alludes in the form of the work, but not only, to Plato's dialogues, introducing us to a "diegematic dialogue $\mathrm{e}^{\prime 50}$. A character called Tychiades (identified with the author) tells his friend Philocles about the events that took place while on his recent visits to their mutual friend, Eucrates, who was ill. When Tychiades entered the room of the patient, his friends were entertaining him by telling supposedly true stories. After this opening frame, the reader is familiarised with the series of ten remarkable stories (or rather an account of these stories). Tychiades, entering Eucrates' room, enters in the middle of the discussion of the most prominent local figures. Besides the host the following are present: Ion the Platonist, Cleodemus the Peripatetic, Arignotus the Pythagorean, Antigonus the Hippocratic and Dinomachus the Stoic. The lineup resembles, not without reason, the Feast by Plato (Ogden 2007, pp. 6-8). When Tychiades hears that they are talking about the miraculous ways to treat Eucrates' leg, he criticizes their naivety and superstition. Unfortunately, those present do not listen to the rational arguments of their opponent, and even start, one by one, telling fantastic stories to convince Tychiades that supernatural events really do happen and that they should be treated very seriously. After each of the stories Tychiades objects, trying to rationalize, or simply mocks the narrator and those who believe him. But his resistance only results in the telling of another story, even more incredible than the previous, which is to finally

49 More about the reception of Lucian please see: Ligota, 2007; Robinson 1979; T. Sinko 1951, pp. 428-435.

50 "Diegematic dialogue" - a dialogue included in the story of the person recounting some conversation. 
convince the doubter. In total, we hear ten of these stories. Scholars have tried to group the stories thematically, but there is no agreement on that subject until now (Ogden 2007, pp. 15-18).

In attempting to identify the origins of the sorcerer's apprentice motif, the last of the stories told in the dialogue seems to be of vital importance. Daniel Ogden in his monograph work on Philopseudes entitled this story, not without reason, the story of The Sorcerer's Apprentice. The tale told by the host himself is about his trip to Egypt, where on a ship sailing on the Nile he met a "holy man" - Pancrates, the Egyptian, who knew spells, and could swim on crocodiles and animated everyday items like pestles, or door bolts. Eucrates said that his new mentor had taught him everything he knew but the secret of animating items. However, the young adept of magic, eager for knowledge, managed to overhear the formula of the secret spell and as soon as his master left, he decided to try it out. The spell worked and a pestle obeyed the order to fetch water in a bucket. Unfortunately, the overzealous student did not know how to stop the animated object. The pestle kept carrying water to the hut and did not obey any other commands. When Eucrates decided to end the spell by force and cut the pestle in half with an axe, he found himself with not one tireless water-carrier, but two of them. The situation was hopeless and Eucrates was close to drowning, but at the last moment, Pancrates appeared and ordered the pestles to become again just the inanimate utensils. After the rescue operation Pancrates left and Eucrates never saw him again. Nonetheless, Tychiades did not believe this story either and, angry at his childish companions, who continued to believe in hoaxes and fairytales, decided to leave the meeting. There the dialogue ends.

Daniel Ogden, in his monograph-commentary to the dialogue Philopseudes, focuses mainly on ancient sources for the story of a young magician. To deduce how Lucian draws inspiration for his stories, he distinguished, for the purpose of his research, a few elements that are vital for the history of the wizardry student. In these features he includes: the presence of a young, overly ambitious student; a desire to learn the spell too powerful for a magician's helper, as well as a book of magic spells or other object which supports casting a spell. Also, D. Ogden includes an object animation, loss of control over the spell and an attempt to bring the animated object to a halt by force, and finally the character of a sorcerer-teacher who refuses to reveal the secret formula, and who at the end rescues the daredevil from a certain death. D. Ogden used these features to investigate the earlier texts in terms of similarity with the text of Lucian (Ogden 2007, pp. 232-248). In this paper they will be used to show the similarity of the later works to the Lucian's text. So let us now get back to the reception of his work.

Lucian's writings continued to inspire various artists for centuries. In the $18^{\text {th }}$ century, the first complete translations of Lucian into national languages appeared, French as the first one. In Germany, a translation of all the works of the Greek writer was done by Christoph Martin Wieland. In 1788, at the invitation of his close friend J. W. Goethe, M. Wieland came to Weimar, where he translated and published the first texts of Lucian. Among them was a translation of dialogue Philopseudes. J. W. Goethe had to know this translation, even if he had read the works of Lucian in Latin translation or even in Greek original before. He 
picked one of the stories told in this dialogue and used its motif to compose one of his most famous ballads, Der Zauberlehrling (The Sorcerer's Apprentice), published in 1797. Goethe's poem based on the Lucianic text became known throughout Europe. A French composer Paul Dukas (1865-1935), under the influence of this piece, which he knew in the French translation by Henri Blaze, composed the symphonic scherzo of the same title (fr. L'apprenti sorcie) and conducted its premiere at a concert of the Société Nationale on 18 May 1897. This scherzo is considered one of the greatest works of so-called programmatic music. P. Dukas characterized his work in the following manner: "The first phrase of violins against a background of violas and cellos can be called a »theme of magic «. This motif contains two thematic elements, the first of which is almost unchanged in the course of the work, while the second is the proper material of the whole (later the bassoon intones it as the »broom theme«). The second theme, very lively and imaginative, characterizes the young student. Finally, the third one, energetically chanted and based on the chromatic chords, is to express »the idea of domination", especially in the postludium, which restores the calm mood of the introduction" (Uczen czarnoksięznika [P. Dukas] 2012). Irving Schwerke commented on the impact of this scherzo on Dukas' life: "A success from the very beginning of its career, this remarkable composition has gone from triumph to triumph and brought universal renown to its author. Indeed, the world-fame of this masterpiece is so overwhelming, it must be accredited with having deprived of similar eminence other masterpieces by this composer" (Schwerke 1928, pp. 402-412).

With the information provided by the composer, and with knowledge of the Goethe's work, Walt Disney Pictures decided to incorporate this theme into their third (after Snow White and Pinocchio) full-length, animated film entitled Fantasia, which was released in cinemas in 1940. The idea of the film lies in combining the masterpieces of classical music with animations and thus interpreting the sound through the image. The soundtrack was recorded by the Philadelphia Orchestra under the baton of Leopold Stokowski. At that time, the production of Fantasia was a big challenge and cost 125 thousand dollars (Finch 1988, pp. 92-102). But the scene itself became a cinema classic. The premiere took place on the 13th November 1940. In 1999 the theme of the sorcerer's apprentice was reactivated in the animated film Fantasia 2000, which was mentioned in the opening paragraph.

This paper has shown so far the how the motif of sorcerer's apprentice originally entered European culture, and then popular culture. These three artistic works, namely Goethe's ballad, Dukas' scherzo and the Disney's film, are inextricably linked. The linking element is the Goethe's poem, without which the further histories of the student of magic would not have been written. Also for this reason, these works are almost identical in terms of narrative. Tracking the action of the film based on the Goethe's ballad, we can observe feature motifs that characterised the story of the sorcerer's apprentice enlisted by D. Ogden (Ogden 2007, pp. 232-248). In the described scene, we can see the Magus (Yen Sid) and the motif in which in absence of the master the young adept of magic arcana (Mickey Mouse) tries to use a book of spells and a magic cap. Mickey Mouse forces a broom to carry water for him, and he falls asleep while the work is being done. He wakes up when the situation is critical, 
and in addition, it turns out that the broom refuses to stop its work and keeps bringing full buckets of water from the well again and again. The desperate apprentice, using an axe, cleaves the disobedient broom into tiny splinters, hoping to get rid of the problem by doing so. But after a while every single splinter magically becomes a new broom, which also starts fetching water. In this way, hundreds of brooms flood the magician's workshop with gallons of water. When it looks as though Mickey Mouse is going to drown, Yen Sid appears and with three energetic gestures saves the situation. It is easy to notice that all the topics contained in that story are almost in the same configuration in Lucian's dialogue.

This topic has been presented slightly differently in the image by J. Turteltaub, who gave the title of The Sorcerer's Apprentice to the whole movie, not just one episode. Nevertheless, the scene with the Dukas' music and Goethe's ballade, which originally inspired the creators of the previous films, takes only 196 seconds in comparison to more than 10-minute episode in the movie Fantasia 2000. In Turteltaub's film the music is based on the Dukas' piece and uses its main musical theme. The film itself tells the story of Dave Stutler, a physics student (played by Jay Baruchel), who turns out to be the last "Merlinian", a descendant of the great magician Merlin, known from Arthurian legends. He begins his magic training with an experienced sorcerer Balthazar (Nicolas Cage). Dave Stutler appears to be a willful and rebellious student. In the absence of the master, he tries to manage to be on time for a date with a girl and under pressure of time uses spells from the magic book to clean the workshop. He not only animates the brooms, but also sponges, soaps, brushes and forces them to work as he leaves the room to prepare for the date. Matters get quickly out of control, and the animated objects instead of cleaning up, become evil and develop free, yet ill, will. They begin smashing and flooding the workshop. Of course Dave's attempts to reverse the spell, after his return to the workshop, fail, and then he nearly gets killed by electrocution. Nonetheless, it is not difficult to guess, that the mag-teacher rescues his student at the last minute. There ends the reference to the Lucian's story in the film. The Lucianic theme therefore is only a minor episode, around which a new story is created and shown on the silver screen. And so, the ancient literary motif remains alive.

However, not only the Walt Disney Studio drew inspiration from the story of Lucian. In the early 60-ies of XX century the theme made famous by the film Fantasia in 1940 was adapted in the famous television series Alfred Hitchcock Presents emitted in 1955-1965 by the American TV stations CBS and NBC. A 25-minute long episode entitled The Sorcerer's Apprentice (directed by Josef Leytes, 1961) should be the $39^{\text {th }}$ in season 7 of the series, though, at the end had been considered too gruesome, and then they changed the formula of the show from about 30 minutes to 1 hour long, and as a result of it the story of mage's apprentice had not been shown on the television. Later on the episode gain the status of Public Domain, which gives the freedom to copy and display the work, and the story adapted in collaboration with A. Hitchcock quickly became one of the most famous in the whole series of Alfred Hitchcock Presents (Grams 2001, pp. 385-388). The scenario was prepared by Robert Bloch, and was based on his short story entitled The Sorcerer's Apprentice, published in a volume of Weird Tales, which was released in 1949, nine years after the premiere 
of Disney's Fantasia. In the Bloch's story a homeless boy named Hugo is taken in by illusionist Sadini, whose prime number in a magic show is a trick of cutting in half, with saw, his beautiful assistant and wife, Irene. Young and naive boy is being used by the magician's wife, who is having an affair and tries to get rid of her husband. She convinces the boy that magic is real and comes from a wand used in the show, and that Sadini sold his soul to Satan, so killing him will not be evil. After the assassination, Hugo wants to see if the magic is still in the wand and decides to test it with the wife-assistant. Unfortunately, the young apprentice did not know the secret of the illusion and he inadvertently cut the woman in half for real causing her death. We learn about her death from the final, sarcastic summary given by A. Hitchcock: "The saw worked excellently, but the wand didn't. Hugo was terribly upset and Irene was beside herself (Leytes 1961).

As it can be seen, the sorcerer's apprentice story is different from the Disney version or Goethe's. However, without a problem the constituent elements for Lucianic version of the story can be to find, such as the presence of a magician (in this case the illusionist), a magical object which does the magic, or the inability to reverse the effects of the spell (in this case, the fatal effect of faith that the magic in show is true). This time, though, the master cannot save his student in the last minute from the consequences of his actions, and apprentice will have to bear the consequences. Despite the differences, this adaptation is part of the Lucianic reception, which is further demonstrated by the takeover of the title of their works by R. Bloch and A. Hitchcock.

As for the problem of Lucian's reception, it must be kept in mind how often Lucian appears as a hypotext for various cultural products (e.g. William Shakespeare and his Timon of Athens, inspired by the dialogue Timon or the Misanthrope). Oft-times the awareness of Lucianic reference has been long lost, as happened in the case of the theme of sorcerer's apprentice. Even though, almost all fantasy literature speaking of space travel is indebted to Lucian and his True story. This is where the first interstellar escapade was described, and this is the setting of the first "star wars", namely the fight between the inhabitants of the Sun and the Moon, with the fantastic troops of horse-vultures, flea-archers, cabbage-wings, etc. Science-fiction and fantasy authors, dealing with the matter of rebellious automatons or other creations of man's hands, use what has been named "the sorce-

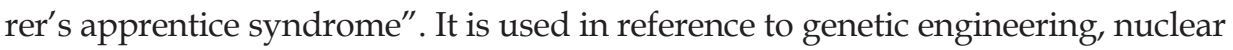
arms, robotics, etc. In R.U.R. (Rossum's Universal Robots), a book written in 1921, Karel Capek, the inventor of the term "robot" and one of the founding fathers of science-fiction, depicts a world of humans more and more overpowered by anthropomorphic robots, where eventually one of them, with the biggest brain in the world, unites the others and leads them into a war against mankind. The original concept of Lucian is still vivid in popular culture (e.g. rebelling robots, mutants, genetic engineering victims or viruses), albeit in a much altered form. Of course, numerous forms of reception of Lucian's works can be named, however the above arguments prove the point well enough, showing that Lucian's heritage is still alive and present - at its fullest in the motif of the sorcerer's apprentice, given to the European culture by the Samostatensis author. 


\section{SOURCES}

Kepler J., (1967), Kepler's Somnium: The Dream, Or Posthumous Work on Lunar Astronomy, Rosen E. (trans.), Courier Dover Publications, Madison.

Lucian (1913-1961), Lucian in Eight Volumes with an English translation by A. M. Harmon, Harvard University Press, Cambridge.

\section{BIBLIOGRAPHY}

Barycz H. (1953), Introtuction to: Erazm z Rotterdamu, Pochwała głupoty, Jędrkiewicz E. (trans.), Ossolineum, Biblioteka Narodowa, Wrocław.

Białostocki J. (ed) (1978), Myśliciele, kronikarze i artyści o sztuce od starożytności do 1500 r., PWN, Warszawa.

Finch Ch. (1988), The Art of Walt Disney: From Mickey Mouse to the Magic Kingdoms, Portland House, New York.

Goldschmidt E. P. (1951), The First Edition of Lucian of Samosata, "Journal of the Warburg and Courtauld Institutes", no. 14.

Grams M., Winstrom P. (2001), The Alfred Hitchcock Presents Companion, OTR Publishing, Churchville. Hammer S. (1948), O bizantyńskich podróżach do piekiet, „Meander” no. 3.

Hardwick L., Stray C. (eds.) (2008) A Companion to Classical Receptions, Blackwell Publishing, Oxford.

Holzman K. (1983), Starożytne i bizantyńskie opinie o Lukianie - pisarzu i człowieku, Meander no. 38.

Holzman K. (1988), Studia o technice literackiej i osobowości twórczej Lukiana, Wydawnictwa Uniwersytetu Warszawskiego, Warszawa.

Korus K. (1968), Michał Bogucki - ttumacz Lukiana, "Meander" no. 10.

Korus K. (1982), Poetyka Lukiana z Samosat. Kryteria oceny i wartościowania, Uniwersytet Jagielloński, Kraków.

Korus K. (2003), Grecka proza poklasyczna, Księgarnia Akademicka, Kraków.

Leśniodorski Z. (1943), Lucjan w Polsce, skł. gł. w Kasie im. J. Mianowskiego, Kraków.

Ligota C. (red.) (2007), Lucian of Samosata. Vivus et Redivivus, Warburg Institute Colloquia, London - Turin.

Madyda W. (1946), Bizantyjska polemika z Lukianem, „Meander” no. 1.

Miziołek J. (2003), "Rodzina centaurów" Louis de Silvestre'a w Pałacach Prezydenckim $i$ w Wilanowie. O recepcji ekphrasis Lukiana w polskiej kulturze artystycznej, „Biuletyn Historii Sztuki” no. 1/2003.

Miziołek J. (2004), Inspiracje śródziemnomorskie, Neriton, Warszawa.

Ogden D. (2004), Eucrates and Demainete: Lucian, "Philopseudes" 27-8, “The Classical Quarterly" no. 54.

Ogden D. (2007), In Search of the Sorcerer's Apprentice: The Traditional Tales of Lucian's Lover of Lies, The Classical Press of Wales, Swansea.

Robinson Ch. (1979), Lucian and his Influence in Europe, The University of North Carolina Press, Chapel Mill.

Schwerke I., (1928), Paul Dukas: A Brief Appreciation, “The Musical Quarterly” XIV (3).

Sinko T. (1951), Literatura grecka, t. 3, Literatura grecka za cesarstwa rzymskiego, part 1, PWN, Kraków.

Sinko Z. (1976), Oświeceni wśród pót Elizejskich. Rozmowy zmarłych. Recepcja. Twórczość oryginalna, Zakład Narodowy im. Ossolińskich, Wrocław.

Winniczuk L. (1978), Lukian a piękno, „Studia Filozoficzne” no. 3.

Wolsza, J. (1994), Opis dzieł malarzy w Dialogach Lukiana. Próba analizy i interpretacji, Acta Universitatis Wratislaviensis, "Antiquitas" no. XIX.

\section{NETOGRAPHY}

Uczeń czarnoksiężnika (Dukas) (2012), http:/ / pl.wikipedia.org, retrieved:20.06. 2012.

\section{FILMOGRAPHY}

Disney W. (1940), Fantasia, Walt Disney Productions.

Hahn D., Glebas F. (1999), Fantasia 2000, Walt Disney Feature Animation.

Leytes J. (1961), Alfred Hitchcock Present, season 7, episode 39: The Sorcerer's Apprentice.

Turteltaub J. (2010), The Sorcerer's Apprentice, Walt Disney Picture. 